\title{
Practiced Gram negative bacteria from dyeing industry effluents snub metal toxicity to survive
}

\author{
Channarayapatna-Ramesh Sunilkumar ${ }^{1,2}$, Lobo Rachel ${ }^{1}$, Gurulingaiah Bhavya ${ }^{1}$, Kujur Swati ${ }^{1,2}$, R. Samaga Sridhar ${ }^{1}$, \\ J. Samanth Kumar ${ }^{1}$, K. Ramachandra Kini ${ }^{1}$, H. S. Prakash ${ }^{1}$, Nagaraja Geetha ${ }^{1 *}$ \\ ${ }^{1}$ Eco-biotech Laboratory, Department of Studies in Biotechnology, Manasagangotri, University of Mysore, Mysuru, Karnataka, India. \\ ${ }^{2}$ Global Association of Scientific Young Minds - GASYM, Mysuru, India.
}

\section{ARTICLE INFO}

Article history:

Received on: 03/01/2017

Accepted on: 07/04/2017

Available online: 14/08/2017

Key words:

Bioremediation, Metal tolerant

bacteria, effluents,

Achromobacter sp,

Stenotrophomonas maltophilia.

\begin{abstract}
Isolation and characterization of metal-tolerant bacteria from dyeing industry effluent was the prime drive of the present investigation. Results yielded during screening and isolation, noted the dominance of bacteria verses fungi; in addition, metal tolerance ability of six out of twenty five bacterial isolates were observed. The six selected isolates were gram's negative, and were identified as Stenotrophomonas maltophilia UOMGNS116, Pseudomonas sp. UOMGNS216, Pseudomonas stutzeri UOMGNS316, Pseudomonas stutzeri UOMGNS416, Citrobacter freundii UOMGNS516 and Achromobacter sp. UOMGNS616 by 16s rDNA analysis. This investigation also evidenced the varied resistance capabilities by Achromobacter sp. UOMGNS616 and Citrobacter freundii UOMGNS516 against chromium and lead by overproduction of external polysaccharides especially against lead.
\end{abstract}

\section{INTRODUCTION}

Sinking up of inorganics especially heavy metals into the ecosystem is due to the disturbing and accelerating nature's slow geochemical cycle by anthropogenic events [1-3]. Expanding industrial areas, mine tailing, disposal of high metal wastes, paints, leading gasoline, application of fertilizers [4], pesticides [5], sewage sludge, waste water irrigation [6, 7], spillage of petroleum chemicals, coal combustion residues [8-10]. Altered biological balance of every living organism because of the enormous complexity of the ecosystem and varying complexity of contaminants from case to case made researchers tough to detail the behaviour of every pollutant. Inability of majority of microbes to oxidize inorganic contaminants similar to organic contaminants [11] and its solubility in aquatic environment increases its ability of accumulation in the food chain [12]. In addition, non-economical physico-chemical or conventional treatment techniques have major shares in increased flow of bulk effluents with complexing organic and metal contaminations to the ecosystem [13]. Survival ability of microbes in harsh environment has attracted the attention of the researchers

* Corresponding Author

Geetha Nagaraj, Eco-biotech Laboratory, Department of Studies in

Biotechnology Manasagangotri, University of Mysore, Mysore, India.

E-mail:geetha@appbot.uni-mysore.ac.in worldwide who are exploring the possibility of addressing the adverse effects of metal pollution by developing simple and comprehensive treatment models [14] employing microbes as work horses to reconstruct the environmental damage posed by heavy metal accumulation. By considering the advantages of understanding native microbial species to design effective biological tool $[15,16]$.

\section{MATERIALS AND METHODS}

\subsection{Collection of effluent samples}

Industrial effluent samples were collected from effluent treatment plant of dyeing industry situated in Bengaluru, India. The samples were collected in pre-sterilized acid washed Pyrex bottles and transported to the laboratory for microbiological assessment.

\subsection{Bacterial isolation and pure culture}

All the three samples were serially diluted up to $10^{-6}$ and inoculated by spread plate method. On LB for bacterial growth, PDA for fungal growth. The LB agar plates were incubated at $35^{\circ} \mathrm{c}$ temperature for 24-48 hours, and PDA plates were incubated at room temperature for 2-3 days. Individual plates were observed and morphologically differentiated colonies were isolated. The isolated colonies were maintained on the slant LB medium. 


\subsection{Determination of heavy metal acceptability of isolates}

All the 25 bacterial isolates were coded serially as UOMGNS01 to UOMGNS25. Individual isolates were inoculated on LB amended with different samples (Table 1) at $0.2 \mathrm{mM}$ of concentration and plates were incubated at $35^{\circ} \mathrm{C}$ for 48 hours. Based on colonizing ability of bacteria on agar plates, isolates were selected for further experiments.

\subsection{Biochemical characterization of heavy metal tolerant bacteria}

\subsubsection{Gram's reaction}

Gram staining was carried out according to the protocol of Vincent 1970 [17]. Results were confirmed by KOH solubility test, was performed according to [18].

The other biochemical test includes, Catalase, Urease, starch hydrolysis, DNA hydrolysis (DNase test) and Lipase as describe by Hankin and Anagnostakis 1970 [19].

\subsubsection{Catalase}

A loopful of bacterium of $24 \mathrm{~h}$ old culture was mixed with a toothpick on a clean glass slide with a drop of $3 \%$ Hydrogen peroxide solution and observed for the presence or absence of air bubbles/froth formation on the slide.

\subsubsection{Urease}

Urease test was done using Stuart's Urea broth (SUB) (Yeast extract-0.1g, potassium phosphate monobasic-9.1g, potassium phosphate dibasic-9.5g, urea- $20 \mathrm{~g}$, phenol red- $0.01 \mathrm{~g}$ ). To $3 \mathrm{ml}$ of SUB a loop full of isolated cultures were inoculated and incubated at $35{ }^{\circ} \mathrm{C}$ with $75 \mathrm{rpm}$. The broth was observed for the colour change at 12,24 and $48 \mathrm{hrs}$.

\subsubsection{DNA hydrolysis (DNase test)}

The production of extracellular enzyme: DNase by bacterial isolates was tested by inoculating the cultures on Difco DNAase agar (tryptone 20g, DNA 2g, NaCl 5g, \& agar $14 \mathrm{~g} ; \mathrm{pH}$ 6). After 3days of incubation, plates were flooded with $1 \mathrm{~N} \mathrm{HCl}$ and observed for clear zone around the colonies which indicates the hydrolysis of DNA in test medium.

\subsubsection{Starch hydrolysis}

The capacity of isolated bacterial cultures to degrade, indicates the ability to produce amylolytic enzyme. This was determined by streak inoculating on to starch agar media $(0.5 \%$ peptone, $0.3 \%$ beef extract, $0.5 \% \mathrm{NaCl}, 1.5 \%$ agar, $0.2 \%$ starchheat to boiling) were incubated at $37{ }^{\circ} \mathrm{C}$ for $72 \mathrm{hrs}$. The hydrolysis of starch was determined by the observation of clear yellow zone around a colony upon addition of Iodine reagent.

\subsubsection{Lipase test/Lipolytic activity}

The test was carried out as described by Sierra (1957). The medium to contain: Difco peptone, $10 \mathrm{~g} ; \mathrm{NaCl}, 5 \mathrm{~g} ; \mathrm{CaCl} 2$ $2 \mathrm{H} 20,0.1 \mathrm{~g}$; agar, $20 \mathrm{~g}, \mathrm{pH} 6$. The Tween 20 per liter was sterilized separately by autoclaved and $1 \mathrm{ml}$ added per $100 \mathrm{ml}$ of sterile and cooled basal medium. The formation of lipolytic enzymes by a colony was seen as either visible precipitate due to the formation of crystals of the calcium salt of the lauric acid liberated by the enzyme or as a clearing of such a precipitate around a colony due to complete degradation of the salt of the fatty acid.

2.5 Molecular characterization of metal tolerant bacteria 2.5.1 Molecular characterization of metal-tolerant bacterial isolates DNA isolation

Genomic DNA extraction and PCR amplification procedures were carried out by following previous standardised protocol of Doyel and Doyel's [20]. Molecular characterization studies were carried out by following protocols detailed previously by Sunil et al., (2015), Total DNA from selected six isolates were used as template to amplify variable region of bacterial 16s rDNA by PCR using the universal primers $6 \mathrm{sF}$ 5' CCAGACTCCTACGGGAGGCAGC-3' and 16sR 5'GCTGACGAGAGCCATGCAGCACC-3' (Sigma Aldrich). The PCR reaction system of $50 \mu 1$ included $5 \mu \mathrm{l}$ of $10 \mathrm{x}$ Taq buffer, $1 \mu \mathrm{l}$ of $0.2 \mathrm{mM}$ dNTPs, $0.15 \mu \mathrm{l}$ of forward and reverse primers (10pmol), $10 \mu \mathrm{l}$ of DNA dilution $100 \mathrm{ng} / \mu \mathrm{l}, 1.75 \mu \mathrm{l}$ of Taq polymerase $(1 \mathrm{U})$ and $37.45 \mu \mathrm{l}$ of nuclease free water and the system was programmed with 30 cycles at $94{ }^{\circ} \mathrm{C}$ for 4 mins, $94{ }^{\circ} \mathrm{C}$ for $45 \mathrm{~s}, 55{ }^{\circ} \mathrm{C}$ for $45 \mathrm{~s}, 72{ }^{\circ} \mathrm{C}$ for $1 \mathrm{~min}$ and $74{ }^{\circ} \mathrm{C}$ for $10 \mathrm{mins}$ (Bio $\mathrm{Rad})$. The results were analyzed by $1.2 \%$ agrose gel electrophoresis.

\subsection{2 nBlast analysis of nucleotide sequence}

All sequences were identified using NCBI nucleotide blast as the selected algorithm, except highly somewhat similar sequences algorithm was chosen to identify the sequence and the Metal tolerant bacterial isolates were identified.

\subsection{Determination of minimal inhibitory concentration of heavy metal tolerant isolates}

Six isolates were inoculated with load of measures inoculum 0.2 optical density measures at $600 \mathrm{~nm}$ using spectrophotometer in $100 \mathrm{ml}$ of pre-autoclaved LB broth amended with $0.2,0.5$ and $1 \mathrm{mM}$ of concentration of Heavy metal salts (Table 1). Culture flasks were incubated at $37{ }^{\circ} \mathrm{C}$ for $74 \mathrm{hrs}$, and turbidity was measured at the time interval of $24 \mathrm{hrs}$ in order to record the growth rate at $600 \mathrm{~nm}$ wave length using spectrophotometer (Beckman coulter DU 700, Germany)

\subsection{Assessing lead acceptability of Achromobacter sp. against Lead}

Achromobacter sp. UOMGNS616 with five other test strains inoculated in $100 \mathrm{ml}$ of pre-sterilized LB amended with 0.2 to $0.5 \mathrm{mM}$ of lead in duplicates were incubated for three days at its optimal conditions and after the incubation period cultures were centrifuged and wet weight of pellets were measured in grams and tabulated against the control flask incubated without any metal stress. 


\section{RESULTS AND DISCUSSION}

\subsection{Determination of microbial load in effluent sample}

\subsubsection{Biochemical characterization of metal tolerant isolates}

3.1.1.1 Determination of optimal growth conditions

Though it is well known that microbes cannot destroy metals, interest among researchers towards understanding the ability of microbes in altering chemical properties of metal is being increasing never than before due to their incredible potentials to survive in harsh metal contaminated environments by employing surprising array of mechanisms [21], which can be exploited for bioremediation of contaminated sites [22]. This investigation was taken up with the intention of evaluating heavy metal tolerance and resistance ability of bacterial consortium habituated in effluents of dyeing industries. Primarily, bacterial dominance especially Gram-negative strains have been observed during the screening studies compared with the fungal load in the effluents. This might be because of increased size of fungal cells with lower density and lower mechanical strength and rigidity when compared with bacterial cells [23]. This result supports the earlier reports on inability of fungal cells to develop equal competence against bacterial cells in heavy metal contaminated sites [24]. Amongst twenty five bacterial isolates only six have been chosen for further studies based on heavy metal acceptability in which all showed to be negative for Gram's staining (Table 1). Results reveal the failure of many bacterial isolates to disclose the adaptive response though they have resided in samples with excessive metals. Further, using partial sequence of their 16s rDNA gene and phylogenetic analysis, the isolates were identified and coded as Stenotrophomonas maltophilia UOMGNS116, Pseudomonas sp. UOMGNS216, Pseudomonas stutzeri UOMGNS316, Pseudomonas stutzeri UOMGNS416, Citrobacter freundii UOMGNS516 and Achromobacter sp. UOMGNS616.
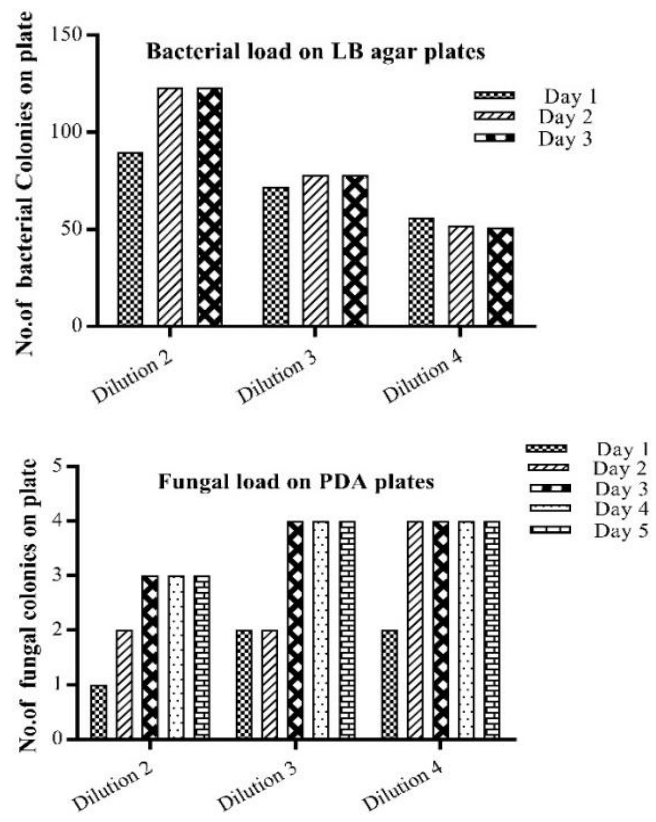

Fig. 1: Bacterial and fungal load in effluent sample on LB agar and PDA plates.
Table 1: Biochemical characterization of multi-metal tolerant bacterial isolates.

\begin{tabular}{|c|c|c|c|c|c|}
\hline Isolates & 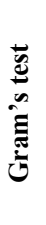 & 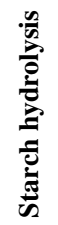 & 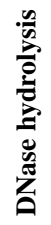 & 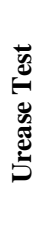 & 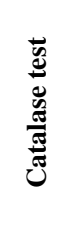 \\
\hline Stenotrophomonas maltophilia UOMGNS116 & - & + & - & - & \\
\hline Pseudomonas sp. UOMGNS216 & - & - & - & - & + \\
\hline Pseudomonas stutzeri UOMGNS316 & - & - & - & - & + \\
\hline Pseudomonas stutzeri UOMGNS416 & - & + & + & - & + \\
\hline Citrobacter freundii UOMGNS516 & - & - & + & - & + \\
\hline Achromobacter sp. UOMGNS616 & - & + & + & - & + \\
\hline
\end{tabular}

All the six isolates have proved their efficiency to multiply in both acidic and alkaline conditions and recoded their individual $\mathrm{pH}$ to grow optimally though they have habituated in neutral $\mathrm{pH}$ environment(Fig: 2).
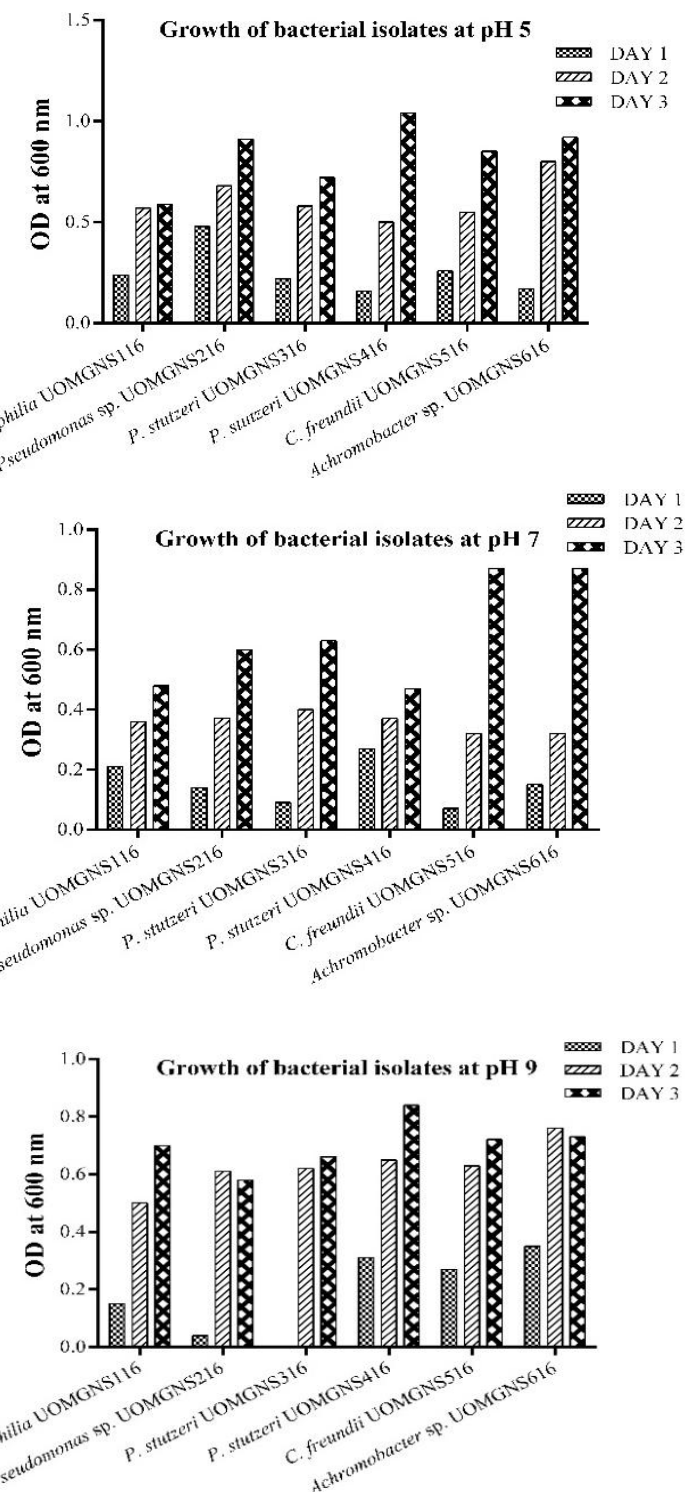

Fig. 2: Determination of optimal $\mathrm{pH}$ of heavy metal tolerant isolates. 
It is important to note the ability of bacteria to survive in alkaline $\mathrm{pH}$ environment which is of widespread importance in remediation in industrial setting [25]. Shifting to an alkaline and acidic environment is stressful for bacteria which involves the responses of key biological molecules [26, 27]. In addition to survival ability, capacity of metal tolerant isolates to grow at optimal rate in both acidic and alkaline conditions extends the interest to study the influence of $\mathrm{pH}$ in gaining tolerance particularly against lead and chromium in future studies. It is also interesting to note that though all the isolates recorded their optimal growth at $35{ }^{\circ} \mathrm{C}$ the survival ability or reproducibility of bacteria at thermostatic environment promises participation in bioremediation at different physiological status (Fig: 3 ).
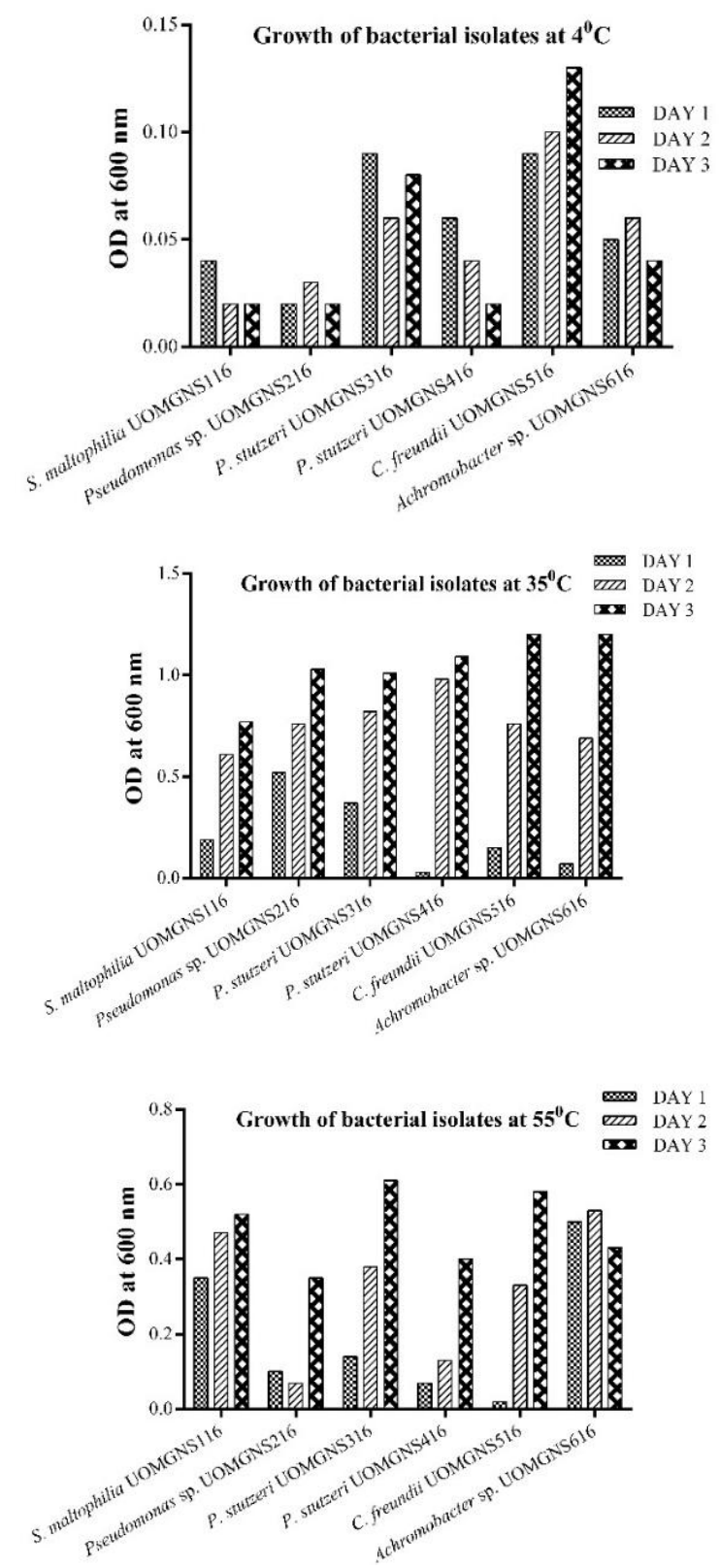

Fig. 3: Determination of optimal temperature for the growth of heavy metal tolerant isolates.
Selected isolates were further subjected to assess their heavy metal tolerance at their optimal growth conditions at increasing metal concentrations. Growing ability of all the test isolates were determined by measuring turbidity of medium due to bacterial growth, all the six isolates failed to survive at low concentrations of cadmium and mercury (data not shown), but exhibited varied tolerance ability against chromium and lead at different concentrations ranging from 0.2 - 1mM (Fig: 4 \& 6).
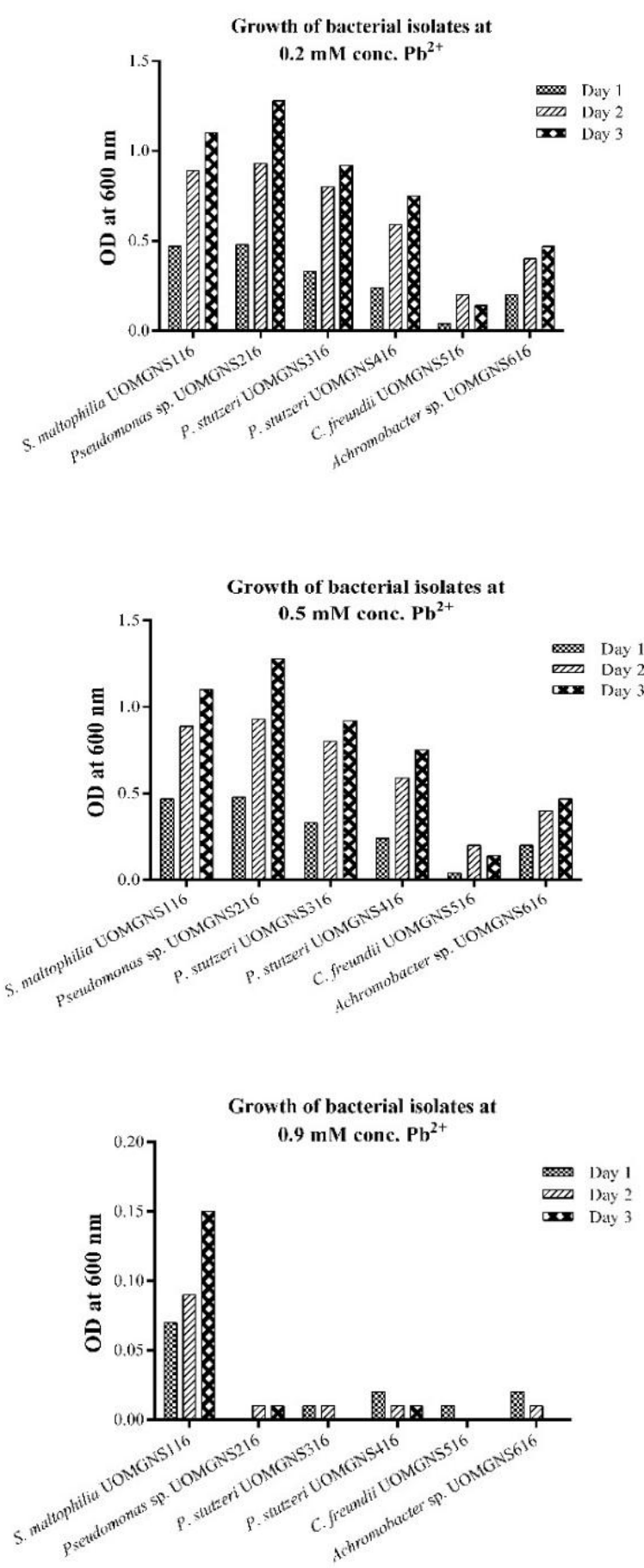

Fig. 4: Determination of minimal inhibitory concentration against different concentration of lead. 


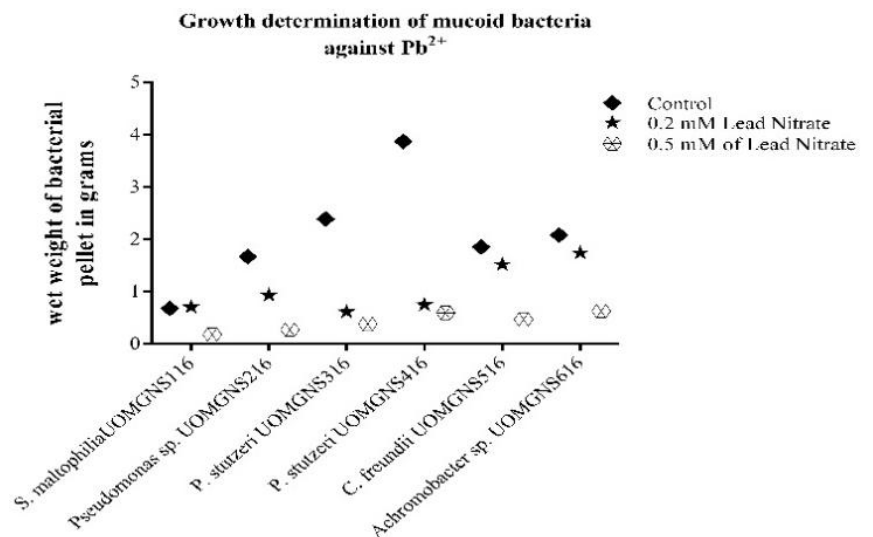

Fig. 5: Determination of growth rate of metal tolerant isolates against lead by measuring wet weight of pellets.
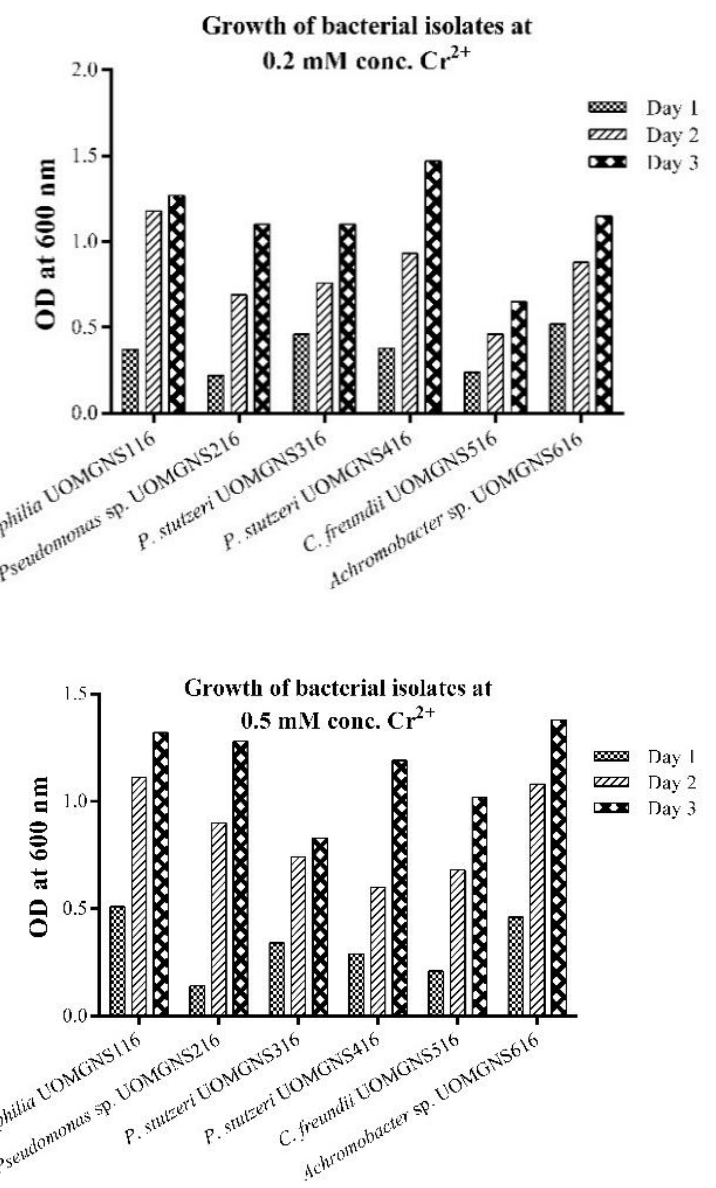

All the six isolates showed gradual increase in their growth measured at every $24 \mathrm{hrs}$ time interval and proved to be equally potent to multiply at $0.2 \mathrm{mM}$ concentration of chromium. At higher concentrations of 0.5 and $1 \mathrm{mM}$ chromium all the isolates except Achromobacter sp. UOMGNS616 and C. freundii retained their tolerance ability (Fig: 6). Minimal inhibitory concentration of lead was estimated for all the six isolates by incubating at different lead concentrations ranging from 0.2 $0.9 \mathrm{mM}$. This study revealed the ability of Stenotrophomonas maltophilia UOMGNS116, Pseudomonas sp. UOMGNS216,
Pseudomonas stutzeri UOMGNS316, Pseudomonas stutzeri UOMGNS416 to multiply at both 0.2 and $0.5 \mathrm{mM}$ conc (Fig: 4). Only C. freundii UOMGNS516 and Achromobacter sp. UOMGNS616 failed to grow at these concentrations when growth determined by measuring turbidity. It is possible that bacteria acquire resistance against metals by preventing the access of metals to sensitive cellular components or by altering them to reduce the sensitivity [28]. In the present investigation mucoid phenotype was noticed in C. freundii UOMGNS516 and Achromobacter sp. UOMGNS616 which is indicative of production of external polymeric substances (EPS) by these isolates [29]. In order to determine growth of mucoidal phenotype produced by $C$. freundii UOMGNS516 and Achromobacter sp. UOMGNS616 the wet weight was measured and compared with all other test isolate at 0.2 and $0.5 \mathrm{mM}$ conc. In supports evidenced the significant tolerance ability of C.freundii UOMGNS516and Achromobacter sp. UOMGNS616 (Fig: 5). Results of the present study evident the potentiality of $C$. freundii UOMGNS516 and Achromobacter sp. UOMGNS616 in heavy metal tolerance. Further characterization of these isolates by biochemical and molecular tools is required before they can be employed for lead clean-up activites of industrial effluents. Further studies are also required to understand the varied metal tolerant potency of $S$. maltophilia UOMGNS116 compared with other co-habitats.

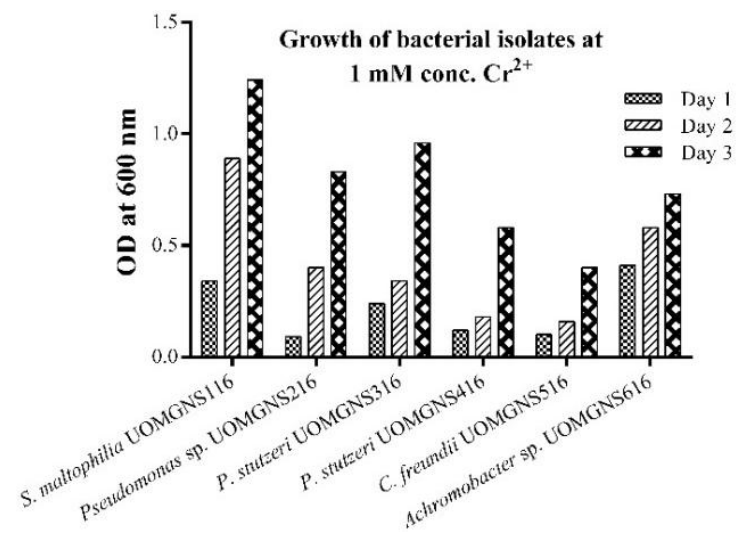

Fig. 6: Determination of minimal inhibitory concentration of metal tolerant isolates against chromium

\section{CONCLUSION}

A result of the present investigation reveals varied behaviour of bacterial consortium isolated from effluents and strongly highlights the importance of understanding acquired resistance of $C$. freundii UOMGNS516 and Achromobacter sp. UOMGNS616 against lead. In future, studies on communication of bacteria to detect specific metal stress in the external environment and communication with its own neighbour cells to lock and unlock the adaptive responses may reveal new clues towards developing sustainable biological clean-up tools. In addition, results also support the importance of understanding biochemical and molecular abilities of S. maltophilia UOMGNS116 acquired in order to sustain in different harsh environments. 


\section{ACKNOWLEDGEMENT}

Financial support and sponsorship: Authors thank to University Grants Commission, New Delhi for financial support and Institution of Excellence, University of Mysore, Mysuru for providing research facilities.

Conflict of Interests: There are no conflicts of interest.

\section{REFERENCES}

1. D'amore JJ, Al-Abed SR, Scheckel KG, Ryan JA. Methods for speciation of metals in soils. Journal of Environmental Quality. 2005; 34(5):1707-45.

2. Sposito G, Page AL. Cycling of metal ions in the soil environment. Metal ions in biological systems. 1984; 18:287-332.

3. Armah FA, Quansah R, Luginaah I. A systematic review of heavy metals of anthropogenic origin in environmental media and biota in the context of gold mining in Ghana. International Scholarly Research Notices. 2014.

4. Raven PH, Berg LR, Johnson GB. Environment. Saunders College Publishing. 2nd ed. New York, NY, USA; 1998.

5. Jones LHP, Jarvis SC. The fate of heavy metals. The Chemistry of Soil Processes. 1981; 593-620.

6. Reed SC, Crites RW, Middlebrooks EJ. Natural systems for waste management and treatment. $2^{\text {nd }}$ ed. McGraw-Hill, Inc.; 1995.

7. Bjuhr J. Trace metals in soils irrigated with waste water in a Periurban area downstream Hanoi City, Vietnam, Seminar Paper, Institutionen for Markvetenskap, Sveriges lantbruk- ' Suniversitet (SLU), Uppsala, Sweden, 2007.

8. Babel S, Kurniawan TA. Cr (VI) removal from synthetic wastewater using coconut shell charcoal and commercial activated carbon modified with oxidizing agents and/or chitosan. Chemosphere. 2004; 54(7):951-967.

9. Sörme L, Lagerkvist R. Sources of heavy metals in urban wastewater in Stockholm. Science of the Total Environment. 2002; 298(1):13145.

10. Gunatilake SK. Methods of removing heavy metals from industrial wastewater. Methods. 2015; 1(1).

11. Kirpichtchikova TA, Manceau A, Spadini L, Panfili F, Marcus MA, Jacquet $\mathrm{T}$. Speciation and solubility of heavy metals in contaminated soil using X-ray microfluorescence, EXAFS spectroscopy, chemical extraction, and thermodynamic modeling. Geochimica et Cosmochimica Acta. 2006; 70(9):2163-2190.

12. Kurniawan TA, Chan GY, Lo WH, Babel S. Physico-chemical treatment techniques for wastewater laden with heavy metals. Chemical Engineering Journal. 2006; 118(1):83-98.

13. Malik A. Metal bioremediation through growing cells. Environment International. 2004; 30(2):261-78.

14. Schwarzenbach RP, Escher BI, Fenner K, Hofstetter TB, Johnson CA, Von Gunten U, Wehrli B. The challenge of micropollutants in aquatic systems. Science. 2006; 313(5790):1072-1077.

15. Boopathy R. Factors limiting bioremediation technologies. Bioresource Technology. 2000; 74(1):63-67.

16. Sunil KCR, Swati K, Bhavya G, Nandhini M, Veedashree M, Prakash HS, Kini KR, Geetha N. Streptomyces flavomacrosporus, A multi-metal tolerant potential bioremediation candidate isolated from paddy field irrigated with industrial effluents. Int. J. of Life Sciences. 2015; 3(1):9-15.
17. Vincent JM. A manual for the practical study of the root-nodule bacteria. A manual for the practical study of the root-nodule bacteria. 1970.

18. James GC, Sherman N. Microbiology: A laboratory manual. Benjamin Publishing Co. Inc, California, 1987.

19. Hankin L, Anagnostakis SL. The use of solid media for detection of enzyme production by fungi. Mycologia. 1975; 1:597-607.

20. Doyle J. DNA protocols for plants. In Molecular techniques in taxonomy. Springer Berlin Heidelberg 1991, pp. 283-293.

21. Lloyd JR. Bioremediation of metals; the application of microorganisms that make and break minerals. Interactions. 2002; 2:M2.

22. Nancharaiah YV, Mohan SV, Lens PN. Biological and bioelectrochemical recovery of critical and scarce metals. Trends in biotechnology. 2016; 34(2):137-155.

23. Kapoor A, Viraraghavan T. Fungal biosorption - an alternative treatment option for heavy metal bearing wastewaters: a review. Bioresource technology. 1995; 53(3):195-206

24. Zouboulis AI, Loukidou MX, Matis KA. Biosorption of toxic metals from aqueous solutions by bacteria strains isolated from metalpolluted soils. Process Biochemistry. 2004; 39(8):909-916.

25. Padan E, Bibi E, Ito M, Krulwich TA. Alkaline $\mathrm{pH}$ homeostasis in bacteria: new insights. Biochimica et Biophysica Acta (BBA)Biomembranes. 2005; 1717(2):67-88.

26. Schuldiner S, Agmon V, Brandsma J, Cohen A, Friedman E, Padan E. Induction of SOS functions by alkaline intracellular $\mathrm{pH}$ in Escherichia coli. Journal of Bacteriology. 1986; 168(2):936-9.

27. Maurer LM, Yohannes E, Bondurant SS, Radmacher M, Slonczewski JL. pH regulates genes for flagellar motility, catabolism, and oxidative stress in Escherichia coli K-12. Journal of Bacteriology. 2005; 187(1):304-19.

28. Rouch DA, Lee BT, Morby AP. Understanding cellular responses to toxic agents: a model for mechanism-choice in bacterial metal resistance. Journal of industrial microbiology. 1995; 14(2):132-41.

29. François F, Lombard C, Guigner JM, Soreau P, Brian-Jaisson F, Martino G, Vandervennet M, Garcia D, Molinier AL, Pignol D, Peduzzi J. Isolation and characterization of environmental bacteria capable of extracellular biosorption of mercury. Applied and Environmental Microbiology. 2012; 78(4):1097-106.

\section{How to cite this article:}

Sunilkumar CR, Rachel L, Bhavya G, Swati K, Sridhar RS, Samanth Kumar J, Kini KR, Prakash HS, Geetha N. Practiced Gram negative bacteria from dyeing industry effluents snub metal toxicity to survive. J App Biol Biotech. 2017; 5 (04): 037-042. 